\title{
The Training Curriculum Development in the Title of "Genius Youth: The Tourist Helper Volunteer under Kalasin Municipality, Kalasin Province."
}

\author{
Asst. Prof. Dr. Teeradet Chuenpraphanusorn \\ Mr. Sarawut Chombuathong
}

Ms. Kanchulee Moonlaphat

Suan Dusit Rajabhat University

E-mail: teere_det@hotmail.co.th

\section{Doi:10.5901/mjss.2014.v5n2p447}

\section{Abstract}

The purpose of this research are 1) to study and survey the need of participants for curriculum development 2) to develop the training curriculum and 3) to evaluate the training curriculum. The populations of this research are teachers, educational officers of Kalasin Municipality and the tourism officers by the accidental sampling method. The sampling groups are 92 teachers, 16 educational officers of Kalasin Municipality and 24 of tourist officers, totally 132 persons. The questionnaire is the main tool for data collecting in 0.93 of Reliability, and the data analysis by statistics in term of percentage mean and standard deviation. The result (s) reveal into 3 steps by the following explanations; Step 1, to study and survey the need of participants for curriculum development. 1. Mostly of the sampling group are 98 of females (74.24\%), the age are more than 40 years in 58 persons (43.94\%), and there are 92 teachers (69.70).2. The necessary of the knowledge and training activities or training methods are in highly rank (means $=4.32$ and standard deviation $=0.47$ ), especially, the necessary of knowledge in tourism industry is in the first priority and the training activities are following. Step 2, the development of training curriculum. The new curriculum is consisted of the name of the curriculum, the objectives of curriculum, subjects, course description, training activities or training methods, materials, the assessment and evaluation processes and the criteria for grading and passed the training program.Step 3, the curriculum evaluation. 1. For the curriculum capacity, it was found that the new curriculum is available for Thai society, because the people in all community can participate in this project very well. Thailand has a various types of tourism destination, so the development of the tourist helper volunteer is the main point of project and can be making the impressive for the foreigner tourist. 2. Subjects in this curriculum are in suitable for training the youth, because the tourist helper volunteer can practice in real situation by graining some knowledge both inside and outside of the classroom context. Another reason, there are the new subjects such as the Persuasive Communication, Personal Development for Voluntary Jobs, Effective Team - Working Technique, Local Knowledge and Consciousness Enhancement in Hometown. 3. The training activities or training methods are obviously for training and it's also preparing in pre-test and posted-test for evaluate the participants before and after training.

Keywords: Training Curriculum Development, Curriculum Development, Tourist Helper Volunteer

\section{Rational for Study}

For many centuries ago, Thailand education is rapidly changed in various aspects for developing Thai people in order to promoting the country for civilization. There is five year strategic plan, based on a collective vision of Thai society as a "Green and Happy Society," where Thai people are endowed with morality-based knowledge and resilience against the adverse impacts of globalization.

The main emphasis of The National Development Plan is depending on the three main types of Education and learning style such as 1) Formal Education in Early Year Education, Basic Education, Vocational Education and Higher Education 2) Non- Formal Education and 3) Informal Education that it was published in the 11st of Thailand National Development Plan but the main purpose of these are also to increase capacity for the improvement of quality of life of our people.

In this regard, the Eleven Plan sets specific targets for education: 1. Increase the average period of education provided to 10 years. 2. Improve test scores (higher than 55\%) in core subjects, at all levels. 3. Raise the percentage of mid-level workforce to $60 \%$ of the national labor force.4. Increase the ratio of research personnel to population by 10:10000. (Bureau of International Cooperation, available on the www.bic.moe.go.th) and (with active MINDS Consulting, 
available on the www.activemindsconsulting.com)

Even form the above mentioned, it seemed to be Thailand's education concentrate in promoting the Formal Education only but in contrary it also promoted another types of Education too, such as the Non- Formal Education.

The Non-formal Education is one of another type of Thailand's education, which it always concerns in the way of life of people in our country, and then it was developed in the lifelong learning style.

The Life Long Learning is one of the major types of Education in Non Formal Form that it still also concerns the society very well as well as another types of Education, because, it has long given priority to adult and non-formal education as a means of providing lifelong learning opportunities to the out of-school population.

Initially aimed at literacy and primary levels, Non-formal education services have expanded significantly into secondary and vocational levels. Strategies include: developing a range of life skills through distance learning, establishing workplace and community learning centres and promoting the joint sharing of resources with the formal school sector In order to support the promotion of a lifelong learning culture in the non-formal education sector, internet connections have been made increasingly accessible in rural areas and system improvements have been implemented to provide recognition of prior learning and facilitate credit transfer .Informal Education The vision of developing a learning society includes.

In Kalasin province, especially in the Municipality area, there are many youths who are suffering from their way of life such as uneducated, lack of opportunity, living in the remote area, live in genteel poverty. These factors are also the main week point of Kalasin Municipality, so the governor tries to solve these problems and get the youth rid of from their suffering by promoting and develop the youths in the right way.

It can be said that the best way for the youth's improvement is the Education, but there are also some questions that what the suitable education for Kalasin Youth is?, the answer is Non-formal Education in lifelong Learning style, nearly as the best way for answering this question.

So, the governor of Kalasin Municipality planed to develop the capacity of the Kalasin's youth in the Non-formal education form by develops the training curriculum in the title of "Genius Youth: the Tourist Helper Volunteer.

Because, Kalasin province is famous for the tourist attraction, it seems to be the best destination of the Northeastern of Thailand. There are a lot of tourist always visit this province more than 300,000 persons for each year. This is the strong reason that why the Kalasin Municipality and governors are also agree for this reason and finally want to train the youth of Kalasin to be the Genius Youth or the Tourist Helper Volunteer.

\section{Objectives of Research}

1. To study and survey the need of participants for curriculum development.

2. To develop the training curriculum in the title of "Genius Youth: the Tourist Helper Volunteer.

3. To evaluate the training curriculum.

\section{Research Methodologies}

The method of this research was divided into three steps by the following explanation;

Step 1) the survey and need analysis of research participants for curriculum development.

Step 2) the curriculum development by the participatory method and discussion.

Step 3) the evaluation of the training curriculum by expertise in critical and discussion form.

\section{Population and Sampling Group (Participants)}

In this research, the sampling group was the same group of the population that the researcher was divided into 2 groups; 1) 92 teachers of Kalasin Municipality School and 16 educators or the educational supporters of Kalasin Municipality were selected all, totally 108 persons, and 2) 24 officers of the tourism business and hospitality section by the accidental Sampling method. The sampling groups were totally 132 persons.

\section{Research Tools}

There were two types of tools in this research;

1. the questionnaire was the main tool for data collecting in 0.93 of Reliability, and then analysis the data by 
statistics in term of percentage (\%), mean (x), and standard deviation (S.D.).

2. the documentary resources took action as the supporting tools for curriculum development such as the policy, vision and mission of Kalasin Municipality in educational management and educational promoting for the youth.

\section{Method of Data Collecting}

From research tools, the method of data collecting can be concluded by the following table;

Table 1: Method of Data Collecting

\begin{tabular}{|l|l|l|l|l|l|}
\hline \multicolumn{1}{|c|}{ Research Step } & \multicolumn{1}{c|}{ Objectives } & Research Question & \multicolumn{1}{c|}{ Method of Study } & \multicolumn{1}{c|}{ Sources } & \multicolumn{1}{c|}{ Output } \\
\hline $\begin{array}{l}\text { Step 1) the survey } \\
\text { and need analysis of } \\
\text { research participants } \\
\text { for curriculum } \\
\text { development. }\end{array}$ & $\begin{array}{l}\text { To study and } \\
\text { survey the need } \\
\text { of participants for } \\
\text { curriculum } \\
\text { development. }\end{array}$ & $\begin{array}{l}\text { What are the real } \\
\text { needs of the } \\
\text { participants and the } \\
\text { stakeholders in the } \\
\text { Tourist Helper } \\
\text { Volunteer curriculum } \\
\text { development? }\end{array}$ & $\begin{array}{l}\text { - Documentary study } \\
\text { and analysis. } \\
\text { - Survey the need of } \\
\text { the participants. }\end{array}$ & $\begin{array}{l}\text {-Document } \\
\text {-Book, vision, } \\
\text { mission of Kalasin } \\
\text { Municipality in } \\
\text { Educational } \\
\text { management } \\
\text { - Questionnaire }\end{array}$ & $\begin{array}{l}\text {-Results from } \\
\text { documents and } \\
\text { Curriculum } \\
\text { development }\end{array}$ \\
\hline $\begin{array}{l}\text { Step 2) the } \\
\text { curriculum } \\
\text { development by the } \\
\text { participatory method } \\
\text { and discussion. }\end{array}$ & $\begin{array}{l}\text { To develop the } \\
\text { training curriculum } \\
\text { in the title of } \\
\text { "Genius Youth: } \\
\text { the Tourist Helper } \\
\text { Volunteer. }\end{array}$ & $\begin{array}{l}\text { Which contents and } \\
\text { activities are suitable } \\
\text { for training the } \\
\text { Kalasin youth? }\end{array}$ & $\begin{array}{l}\text {-Documentary } \\
\text { analysis } \\
\text {-Action participatory } \\
\text { method in curriculum } \\
\text { development }\end{array}$ & $\begin{array}{l}\text {-Documentary } \\
\text {-Book, vision, } \\
\text { mission }\end{array}$ & $\begin{array}{l}\text { - Related literature } \\
\text { from unit 2 } \\
\text { title of "Genius } \\
\text { the Tourist Helper } \\
\text { Volunteer under } \\
\text { Kalasin Municipality } \\
\text { for training. }\end{array}$ \\
\hline $\begin{array}{l}\text { Step 3) the } \\
\text { evaluation of the } \\
\text { training curriculum by } \\
\text { experts in critical and } \\
\text { discussion form. }\end{array}$ & $\begin{array}{l}\text { To evaluate the } \\
\text { training } \\
\text { curriculum. }\end{array}$ & $\begin{array}{l}\text { The training } \\
\text { curriculum is } \\
\text { suitable for training } \\
\text { the Kalasin youths } \\
\text { or not? }\end{array}$ & $\begin{array}{l}\text { The evaluation by } \\
\text { experts in the } \\
\text { relevant of the } \\
\text { curriculum for training } \\
\text { the Kalasin's youth. }\end{array}$ & $\begin{array}{l}\text { New Training } \\
\text { Curriculum }\end{array}$ & $\begin{array}{l}\text { New efficiency } \\
\text { curriculum for training } \\
\text { the youth. }\end{array}$ \\
\hline
\end{tabular}

\section{Results of Research}

The result of the curriculum development is presented in three sections by the following step;

\subsection{Step 1) the survey and need analysis of research participants for curriculum development.}

1. The demographic of participants, mostly of the sampling group are 98 of females $(74.24 \%)$, the age are more than 40 years in 58 persons (43.94\%), and there are 92 teachers (69.70).

2. The necessary of the knowledge and contents are in highly rank (means $=4.35$ and standard deviation = 0.48), especially, the necessary of foreign language communication skills in English, Chinese, Japanese or another language are in the first priority of this curriculum, and then this curriculum must have many subjects for preserving and protection the natural environment in Kalasin province, self- esteem in their local wisdom, local life and OTOP products are in secondary rank, and the third; this curriculum must have the persuasive communication for helping many tourists or visitors when they are visiting Kalasin, or the tourist helping training course (first aids) in case the tourist had an accident in Kalasin province, a youth's consciousness enhancement in their hometown, and some knowledge management and accommodation providing in tourism industry, especially in Kalasin Municipality context.

3. The training activities or training methods are in highly rank (means $=4.25$ and standard deviation $=0.53$ ), especially, the practicum should be held on the real-life situation contexts and interesting places such as temples, monasteries, monastic compounds, historical places, natural places surrounding around Kalasin Municipality are needed. The local wisdom gurus or specialist or experts are also necessary for this curriculum too, that these details can be seen in table 2 . 
Table 2: The Average Score of Means and Standard Deviation of the Necessary of the Training Activities or Training methods.

\begin{tabular}{|c|c|c|c|c|}
\hline $\begin{array}{l}\text { The necessary of the training activities } \\
\text { or training methods }\end{array}$ & $\overline{\mathbf{X}}$ & S.D. & $\begin{array}{l}\text { Necessary } \\
\text { level }\end{array}$ & Ranking \\
\hline 1. Training program should held on Saturday and Sunday & 3.78 & 1.01 & height & 8 \\
\hline $\begin{array}{l}\text { 2. The sequence of subjects for training should considered from the necessary and } \\
\text { usefulness such as, voluntary psychology should be the first subject or etc. }\end{array}$ & 4.17 & 0.69 & height & 7 \\
\hline 3. Training program should be included between content and practicum in 50 and $50 \%$ & 4.29 & 0.73 & height & 5 \\
\hline $\begin{array}{l}\text { The youth should practice in real-life situation and places such as the temple, } \\
\text { monasteries, natural places. }\end{array}$ & 4.43 & 0.68 & height & 1 \\
\hline $\begin{array}{l}\text { The English communicative skills in giving information, direction, and explanation } \\
\text { for tourist helping should be concentrated. }\end{array}$ & 4.35 & 0.65 & height & 3 \\
\hline $\begin{array}{l}\text { The local wisdom gurus or specialist or experts are also necessary for the guest } \\
\text { speaker or trainer of the youth. }\end{array}$ & 4.42 & 0.65 & height & 2 \\
\hline $\begin{array}{l}\text { 7. The special guest speakers are also necessary for this curriculum such as, the } \\
\text { expertise in law or the expertise in first aids. }\end{array}$ & 4.32 & 0.70 & height & 4 \\
\hline 8. It should be pre-test and post-test before and after training. & 4.27 & 0.71 & height & 6 \\
\hline Total & 4.25 & 0.53 & height & \\
\hline
\end{tabular}

\subsection{Step 2, the development of the training curriculum}

The new curriculum is consisted of the name of the curriculum, the objectives of curriculum, subjects, course description, training activities or training methods, materials, the assessment and evaluation processes and the criteria for grading and passed the training program that it can be present by the following explanation;

1. The name of the curriculum "Genius Youth: the Tourist Helper Volunteer under Kalasin Municipality, Kalasin Province."

2. The objectives of curriculum are;

a) Have knowledge and capacity in helping the tourist.

b) Able to communicate in foreign language, has a critical thinking skills and discussion.

c) Positive attitude, moral, ethics, understand the role of the volunteer with service mind and public mind.

3. The capacity of the youth with their duties that can be found in table 3

Table 3: The capacity of the youth with their duties.

\begin{tabular}{l|l}
\hline \hline The capacity of the youth & The duty that its relevance with capacity \\
\hline 1 Have knowledge and capacity in helping the tourist. & $\begin{array}{l}\text { 1. Study and practice in helping tourist with moral and ethic integrated in } \\
\text { every subject. }\end{array}$ \\
\hline $\begin{array}{l}\text { 2. Able to communicate in foreign language, has a } \\
\text { critical thinking skills and discussion. }\end{array}$ & $\begin{array}{l}\text { 2. Practicing and training in various situations and in real-life time. } \\
\text { 3. Practicing in English language or foreign language in listening and } \\
\text { speaking. } \\
\text { 4. Practicing and training in holistic between critical thinking skills } \\
\text { development and discussion. }\end{array}$ \\
\hline $\begin{array}{l}\text { 3. Positive attitude, moral, ethics, understand the role } \\
\text { of the volunteer with service mind and public mind. }\end{array}$ & $\begin{array}{l}\text { 5. Develop the attitude, moral, ethics, understand the role of the } \\
\text { volunteer with service mind and public mind. }\end{array}$ \\
\hline 4. Good relationship and co-working with colleague. & $\begin{array}{l}\text { 6. Practicing and training for team-work building } \\
\text { 5. Local Information presentation or explanations }\end{array}$ \\
\hline \hline
\end{tabular}

\section{Subject and Course Description}

There are 13 subjects in this curriculum and can be seen in table 4

Table 4: Subjects and Course Description 


\begin{tabular}{|c|c|}
\hline Subject (s) & Course Description \\
\hline 1.Tourist Volunteer & $\begin{array}{l}\text { 1. Study the role of the volunteer, understanding and explain the scope and responsibility of the } \\
\text { tourist volunteer toward the mission and the scope of their works, especially in the tourist safety } \\
\text { awareness with the ethics, moral and respectful of their duties in the Tourist volunteer. }\end{array}$ \\
\hline 2.Consciousness & 2. Study the techniques and methods in sustainable management, promoting and creating the \\
\hline Enhancement in & strongly community. Create the conscious, roles, functions and importance factors for the host \\
\hline Hometown & $\begin{array}{l}\text { country by practicing in tourist welcoming, the good attitude toward the tourist service for impressive } \\
\text { and identity building. }\end{array}$ \\
\hline 3.Personal & 3. Study the principles, guidelines for personal development in business service both inside and \\
\hline $\begin{array}{l}\text { Development for } \\
\text { voluntary Jobs }\end{array}$ & $\begin{array}{l}\text { outside such as social manner, self-conduct, self-confidence, encouragement for preparing } \\
\text { themselves in tourist volunteer service. }\end{array}$ \\
\hline 4.Local Knowledge & $\begin{array}{l}\text { 4. Study the history, geography, wisdom, dialect, arts, tradition and custom by using the presentation } \\
\text { technique in various methods for enquiry the tourist's knowledge in the local area. }\end{array}$ \\
\hline 5.Principles of Tourism & $\begin{array}{l}\text { 5. Study the concept, component, forms and the contemporary tourism situations, roles and the } \\
\text { importance of tourist towards the local as well as negative impacts of tourist development which lead } \\
\text { to the study of sustainable tourism management. This subject is designed for classroom context with } \\
\text { the case studies and field trip in local area. }\end{array}$ \\
\hline $\begin{array}{l}\text { 6. The Principle of First } \\
\text { Aid }\end{array}$ & $\begin{array}{l}\text { 6. Study the concept, usefulness and the principle of first aid by practicum training in monitoring of } \\
\text { the patient such as high blood pleasure and fever take care. This subject is designed for outside } \\
\text { classroom context with the real situations in many local areas. }\end{array}$ \\
\hline 7. Tourism Law & $\begin{array}{l}\text { 7. Study the meaning and the importance of tourist's law, the governmental principles and tourist } \\
\text { acting by tourist case study that it was relevant with the theories of law. }\end{array}$ \\
\hline $\begin{array}{l}\text { 8.Service- Mind for } \\
\text { Volunteer }\end{array}$ & $\begin{array}{l}\text { 8. Study the meaning, importance, techniques of Service - mind for business service, morals and } \\
\text { ethics for self-adaptation and discussion with others person in cooperative, public relationship } \\
\text { making process between their college and public section. }\end{array}$ \\
\hline 9. Persuasive & 9. Study the meaning, importance, skills, methods, and \\
\hline Communication & $\begin{array}{l}\text { persuasive communication with service mind for business service section. Adapt the psychological } \\
\text { theories and fundamental human behaviors for audience analysis or tourists for changing the tourist } \\
\text { behavior and attitude with the cross cultural communication methods. }\end{array}$ \\
\hline $\begin{array}{l}\text { 10. Effective Team - } \\
\text { Working Technique }\end{array}$ & $\begin{array}{l}\text { 10. Study the meaning, concepts; team-work's building in efficiency such as the activities for creating } \\
\text { the team-wok by communicative approach for relationship and team-work promoting. }\end{array}$ \\
\hline 11. English for Host 1 & $\begin{array}{l}\text { 11.Practice in the listening and speaking English skills for daily use and communicate with tourists of } \\
\text { foreigners in the context of the host country, especially in the tourist places attraction by giving the } \\
\text { direction, recommended the restaurants and shops. }\end{array}$ \\
\hline 12. English for Host 2 & $\begin{array}{l}\text { 12. Practice in the listening and speaking English skills with tourists such as how to suggest tourist } \\
\text { about safety and security and describe how to do and don't when they are staying in Thailand. }\end{array}$ \\
\hline $\begin{array}{l}\text { 13. Foreign Language in } \\
\text { Communication }\end{array}$ & $\begin{array}{l}\text { 13. Practice in the fundamental of listening and speaking Asian language such as Chinese, Laos, } \\
\text { Vietnam, Khmer, Myanmar for daily life by describing the direction and suggestion. }\end{array}$ \\
\hline
\end{tabular}

5. The training activities processes

The activities will be held on by 5 steps of training process as;

- Process 1) Pre-test and Introduction of the training. This process is the first step of training the youth by finding the background of

- knowledge that the youth can be and lack of for preparing and managing the training program.

- Process 2) Introduction of the content

- Process 3) Training Process by teaching with practicum, and activities both inside and outside classroom context.

- Process 4) Conclusion, this process is using the discussion method between lecturer(s) and trainees or trainee and their friends.

- Process 5) Post-test

\subsection{Step 3, the curriculum evaluation}

The evaluation of the training curriculum by 5 expertises in critical and discussion form and the results were found that;

1) For the curriculum capacity, it was found that the new curriculum is available for Thai society. Because, people in all community can be participate in this project very well. Thailand has a various types of tourism destination, so the development of the tourist helper volunteer is the main point of project and can be making 
the impressive for the foreigner tourist.

2) Subjects in this curriculum are in suitable for training the youth, because the tourist helper volunteer can practice in real situation by graining some knowledge both inside and outside of the classroom context. Another reason, there are the new subjects such as the Persuasive Communication, Personal Development for Voluntary Jobs, Effective Team - Working Technique, Local Knowledge and Consciousness Enhancement in Hometown.

3) The training activities or training methods are obviously for training and it's also preparing in pre-test and posted-test for evaluate the participants before and after training.

\section{Conclusion and Discussion}

\subsection{Conclusion}

The research on the title of "The Training Curriculum Development in the title of "Genius Youth: the Tourist Helper Volunteer under Kalasin Municipality, Kalasin Province", can be concluded by the stepping of research into 3 steps by the following explanations;

\subsubsection{Step 1) the survey and need analysis of research participants for curriculum development.}

1. The questionnaires were collected from the teachers, educational officers and the tourist officer in Kalasin Province. The result was reviewed that the demographic of participants of the sampling group mostly are 98 of females $(74.24 \%)$, the age are more than 40 years in 58 persons (43.94\%), and there are 92 teachers (69.70).

2. The necessary of the knowledge and contents are in highly rank (means $=4.35$ and standard deviation $=$ 0.48). Especially, the necessary of foreign language communication skills in English, Chinese, Japanese or another language are in the first priority of this curriculum, and then this curriculum must have many subjects for preserving and protection the natural environment in Kalasin province, self- esteem in their local wisdom, local life and OTOP products are in secondary rank, and the third; this curriculum must have the persuasive communication for helping many tourists or visitors when they are visiting Kalasin, or the tourist helping training course (first aids) in case the tourist had an accident in Kalasin province, a youth's consciousness enhancement in their hometown, and some knowledge management and accommodation providing in tourism industry, especially in Kalasin Municipality context.

3. The training activities or training methods are in highly rank (means $=4.25$ and standard deviation $=0.53$ ), especially, the practicum should be held on the real-life situation contexts and interesting places such as temples, monasteries, monastic compounds, historical places, natural places surrounding around Kalasin Municipality are needed. The local wisdom gurus or specialist or experts are also necessary for this curriculum too.

\subsubsection{Step 2, the development of the training curriculum}

The new curriculum is consisted of the name of the curriculum, the objectives of curriculum, subjects, course description, training activities or training methods, materials, the assessment and evaluation processes and the criteria for grading and passed the training program.

\subsubsection{Step 3, the curriculum evaluation by 5 experts}

1. It was found that the new curriculum is available for Thai society and the volunteer can be one of the participator in this project very well.

2. Every subject in this curriculum is suitable for training the youth because there are many new subjects such as the Persuasive Communication, Personal Development for Voluntary Jobs, Effective Team - Working Technique, Local Knowledge and Consciousness Enhancement in Hometown 


\subsection{Discussion}

The research setting is taking place in Kalasin Province and the main point of this research is in developing the training curriculum for Kalasin's youth. This research is conducted by 3 steps and can be found that the foreign language, especially English is also the necessary of the volunteer because the English language is taking place as the international language. So, the tourist helper should communicate English language with foreigners or tourists very well or efficiency, then the Chinese and Japanese language is persuaded in this curriculum. Furthermore, in the year of 2015, Thailand will participate in ASEAN Community, so the English language may be shift from the foreign language to the second language. For this result was relevant with the research of Teeradet and his college (2010) in The Local Curriculum Development in the title of "Young Tourist Guide for Sustainable Tourism Promotion based on the Philosophy of Sufficiency Economy under Kalasin Municipality School, Kalasin Province that the English language is also the first priority of needs of Thai people. Furthermore, subjects and training activities are also encouraged in this curriculum such as Effective Team - Working Technique, Local Knowledge and Consciousness Enhancement in Hometown.

\section{Suggestions}

1. Even though this research is taking place in Kalasin province but this model and method of curriculum development can be implied in another province in training the youth.

2. The main purpose of this curriculum is pointed in youth training and preparing the youth to be a good volunteer of province, so this activity must be the first priority and good example of another province.

3. This research is finished in curriculum evaluation only, so the outcome of this research is just showing the curriculum document, not beyond to the training method. So, the Kalasin Municipality should held the training curriculum for training their youth and then collecting data and prove the result of training activities that it is efficiency or not for improvement the curriculum in future.

\section{References}

Thai

กรมวิชาการ . (2549). ท้องถิ่นกับการพัฒนาหลักสูตร.กรุงเทพฯ : โรงพิมพ์คุรุสภา.

. (2540). สรุปผลการวิจัยเรื่องภูมิปัญญาท้องถิ่นกับการพัฒนาหลักสูตรและการจัดการเรียน การสอน.กรุงเทพๆ : โรงพิมพ์คุรุสภา.

. (2545ก). แนวการจัดทำหลักสูตรสถานศึกษา.กรุงเทพฯ : คุรุสภาลาดพร้าว.

. (2545ข). หลักสูตรการศึกษาขั้นพื้นฐาน พุทธศักราช 2544 . กรุงเทพฯ : คุรุสภาลาดพร้าว.

. (2545ค). หลักสูตรการศึกษาขั้นพื้นฐาน พุทธศักราช 2544 . (พิมพ์ครั้งที่ 3 ).

กิ่งฟ้า สินธุวงษ์ และคณะ. (2546). รูปแบบการพัฒนาหลักสูตรสถานศึกษาสำหรับบริบทของโรงเรียนในภาค

ตะวันออกเฉียงเหนือ. กรุงเทพฯ : สำนักงานเลขาธิการสภาการศึกษากระทรวงศึกษาธิการ.

คณะกรรมาธิการอุตสาหกรรมและการท่องเที่ยวสภานิติบัญญัติแห่งชาติและการท่องเที่ยวแห่งประเทศไทย. (2550). เอกสาร

ประกอบการประชุมเชิงปฏิบัติการ "ทิศทางท่องเที่ยวไทยบนฐานแนวเศรษฐกิจพอเพียง". (อัดสำเนา).

ชำนาญม่วงทิม. (2541)."สถานภาพของอาชีพมัคคุเทศก์ในปัจจุบัน."คู่มือมัคคุเทศก์. กรุงเทพฯ : มหาวิทยาลัยศิลปากร.

เถกิง สวาสดิพันธ์. (2525)."หน้าที่และความรับผิดชอบของมัคคุเทศก์." มัคคุเทศก์กับการนำเที่ยว.กรุงเทพฯ : พิฆเนศ.

ทัศนีย์ ทองไชย. 2542 . สภาพและแนวทางการนำภูมิปญญาท้องถิ่นมาใช้ในการจัดการเรียนการสอนวิชา สังคมศึกษาใน

โรงเรียนมัธยมศึกษา สังกัดกรมสามัญศึกษา จังหวัดอุบลราชธานี.วิทยนิพนธ์ปริญญาโทมหาวิทยาลัยขอนแก่น.

ธีรเดช ชื่นประภานุสรณ์และคณะ $(2552)$.การพัฒนารูปแบบการเรียนการสอนแบบบูรณาการการสื่อสารด้วยภาษาอังกฤษกับ

คุณธรรมและจริยธรรมสำหรับครูผู้ดูแลเด็กภาคใต้ตอนล่าง : กรณีศึกษานักศึกษาหลักสูตรการศึกษาปฐมวัย

มหาวิทยาลัยราชภัฏสวนดุสิต.คณะมนุษยศาสตร์และสังคมสาสตร์มหาวิทยาลัยราชภัฏสวนดุสิต.

. (2554).การพัฒนาหลลักสูตรท้องถิ่น “มัคคุเทศก์น้อยเพื่อส่งเสริมการเที่ยวอย่างยั่งยืนตามหลักปรัชญา

เศรษฐกิจพอเพียงของโรงเรียนในสังกัดเทศบาลเมืองกาฬสินธุ์ จังหวัดกาฬสินธุ์. คณะมนุษยศาสตร์และสังคม

ศาสตร์มหาวิทยาลัยราชภัฏสวนดุสิต.

. (2553).หลักสูตรมาตรฐานการฝึกอบรมอาสาสมัครช่วยเหลือนักท่องเที่ยว.กองบังคับการตำรวจท่องเที่ยว

สำนักงานตำรวจแห่งชาติ.

บุบผา เมฆศรีทองคำ. $(2545)$. การพัฒนาหลักสูตรเพื่อเสริมสร้างกระบวนการตัดสินใจทางจริยธรรมในวิชาชีพหนังสือพิมพ์

สำหรับนักศึกษาวารสารศาสตร์. กรุงเทพฯ : วิทยานิพนธ์ ปริญญาดุษฎีบัณฑิต. มหาวิทยาลัยศรีนครินทรวิโรฒ 
ประสานมิตร.

บุญเลิศ จิตตั้งวัฒนา. (2548). การพัฒนาการท่องเที่ยวแบบยั่งยืน. ปริญญานิพนธ์มหาบัณฑิตสาขาประชากรศึกษาบัณฑิต

วิทยาลัย มหาวิทยาลัยมหิดล.

เบญูจา จันทรประชุมพรรังษีวงศ์ และพงระภีศรีสวัสด์. (2547). รายงานการวิจัยปัจจัยที่มีอิทธิพลต่อการมีส่วนร่วมของ

ชุมชนท้องถิ่นในการบริหารจัดการด้านการ ท่องเที่ยวเชิงนิเวศในพื้นที่ลุ่มแม่น้ำแม่กลองจังหวัดราชบุรี.

กรุงเทพฯ :มหาวิทยาลัยเทคโนโลยีราชมงคลกรุงเทพ.

พรพิษณุ พรหมศิวะพัลลภ. (2548). รายงานการวิจัยการวัดระดับความพึงพอใจของนักทองเที่ยวต่อผลิตภัณฑ์การท่องเที่ยว

ของจังหวัดภูเก็ตพังงาและกระบี่.สงขลา : คณะอุตสาหกรรมบริการมหาวิทยาลัยสงขลานครินทร์.

รัชนี จาวนิชสกุล. (2550).พฤติกรรมการสอนภาษาอังกฤษของครูต้นแบบ.กรุงเทพฯ : มหาวิทยาลัยศิลปากร.

สำนักงานคณะกรรมการการศึกษาแห่งชาติ. (2545). การพัฒนาหลักสูตรขยายประสบการณ์สำหรับนักเรียน

ที่มีความสามารถพิเศษด้านภาษาไทยระดับมัธยมศึกษาตอนปลาย.กรุงเทพฯ: สำนักงานคณะกรรมการ

การศึกษาแห่งชาติ.

สำนักงานคณะกรรมการการศึกษาแห่งชาติ. (2545). การจัดทำหลักสูตรสถานศึกษา. กรุงเทพฯ :โรงพิมพ์องค์การรับส่งสินค้าและพัสดุภัณฑ์.

สำนักงานคณะกรรมการการศึกษาแห่งชาติ. $(2540$ ก).การสัมมนาทางวิชาการ เรื่องภูมิปัญญญาชาวบ้าน.กรุงเทพๆ: โรงพิมพ์คุรุ

สภา.

\section{English}

Collins Cobuild. (1987). Dictionary Englsih Language.London : William Colins Sons And Col,Ltd.

GutexBerald, L. (1988). Education and Schooling in America. New Jersey : Prentice-Hall.

FilicianoGloria. (1983). Training in the Development and Use of Folk Media and Mass Media in Field Level Communication Strategies.

UNESCO Report Folk Media and massmedia in Population Communication 8 (march) : 8.

LasswellHarold, D. (1960). The Structure and Function of Communication.New York :Happer and Brother.

Luca, I. (2004). ESP Syllabus Design for Tourism Students. Latvia : School of Business Administration Turiba Latvia.

Michaelis, J.U. (1972). Social Studies for Children in a Democracy : Recent Trends and Development. Englewood Cliffs, New Jersey : Prentice-Hall.

Oliva, Peter F. (1988). Developing the Curriculum.( $\left.2^{\text {nded. }}\right)$. Illinois : Scott, Foresman and Company.

Saylor, J. G. and W.M. Alexander. (1974). Planning Curriculum for school. New York: Holt Rinlhast and Winston.

Tan SooiBeng.(1992). Towards a Social Historical Ethnomusicology :Bangsawan as case study.Malaysia.

Taba, H. (1962). Curriculum Development: Theory and Practice. New York : Harcourt, Brace.

Tyler, R.W. (1949). Basic Principles of curriculum and Instruction.Chicago :University of Chicago Press.

http://www.northernstudy.org/Sufficiency_Economy_htm 